\title{
VALORES RELACIONALES
}

El desarrollo humano es un proceso que aumenta las opciones y la libertad de las personas, permitiéndoles alcanzar un mayor nivel de potencial de habilidades y de bienestar. (Naciones Unidas)



Sánchez Vidal, Alipio. Nuevos valores en la práctica psicosocial y comunitaria:autonomía compartida, auto-cuidado, desarrollo humano, empoderamiento y justicia social. Universitas Psychologica, 10/2015, Volumen 14, Número 4. 